\title{
Analysis of the Village Revenue and Expenditure Budget Administration Accounting System (APBDes) in Ulak Paceh Village
}

\section{Analisis Sistem Akuntansi Penatausahaan Anggaran Pendapatan dan Belanja Desa (APBDes) pada Desa Ulak Paceh}

\author{
Eka Sevtia Mesta 1); Ryan Al Rachmat ${ }^{2)}$ \\ 1,2) Program Studi DIII Akuntansi, Politeknik Sekayu \\ Email: ${ }^{1)}$ ekamesta86@gmail.com: ${ }^{2)}$ Ryan-alrachmat@hotmail.co.id
}

\section{How to Cite:}

Mesta, E. S., Rachmat, R. A. (2022). Analysis of the Village Revenue and Expenditure Budget Administration Accounting System (APBDes) in Ulak Paceh Village. Jurnal Ekonomi Manajemen Akuntansi Dan Keuangan, 3(1). DOI: https://doi.org/10.53697/emak.v3i1

ARTICLE HISTORY

Received [19 Desember 2021]

Revised [27 Desember 2021]

Accepted [03 Januari 2022]

\section{KEYWORDS}

Analysis, Procedure,

Accounting, Village

This is an open access article under the CC-BY-SA license

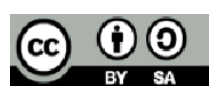

\section{ABSTRAK}

Penelitian bertujuan untuk menghasilkan model sistem penatausahaan akuntansi desa untuk diterapkan di desa-desa sesuai dengan undang-undang dan peraturan pemerintah. Hasil penelitian ini adalah Prosedur Penatausahaan Akuntansi Desa untuk digunakan di desa-desa di Indonesia sebagai pedoman penatausahaan. Teknik analisis data penelitian yaitu mengumpulkan data dari wawancara observasi dan dokumentasi kemudian data tersebut dijadikan bahan untuk Analisis sistem dan prosedur. Hasil dari penelitian ini ditemukan bahwa pegawai penatausahaan akuntansi desa Ulak Paceh perlu mempelajari undang-undang dan peraturan pemerintah ketika melakukan penatausahaan akuntansi desa. Dengan keterbatasan kompetensi mereka dibidang akuntansi dan administrasi kegiatan penatausahaan ini sangat menyulitkan mereka. Dengan adanya analisis sistem akuntansi penatausahaan APBDes pada desa Ulak Paceh diharapkan agar kegiatan penatausahaan pada desa Ulak Paceh menjadi lebih baik dari sebelumnya.

\section{ABSTRACT}

This study aims to produce a model of the village accounting administration system to be applied in villages in accordance with government laws and regulations. The result of this study is the Village Accounting Administration Procedure to be used in villages in Indonesia as an administrative guideline.. The research data analysis technique is collecting data from observation interviews and documentation and then the data is used as material for system and procedure analysis. The results of this study found that Ulak Paceh village accounting administration employees need to learn the laws and government regulations when administering village accounting. With their limited competence in the field of accounting and administration, this administrative activity is very difficult for them. With the analysis of the APBDes administrative accounting system in Ulak Paceh village, it is hoped that administrative activities in Ulak Paceh village will be better than before.

\section{PENDAHULUAN}

Desa adalah kesatuan masyarakat hukum yang memiliki batas wilayah yang berwenang dan mengurus urusan pemerintahan, kepentingan masyarakat setempat berdasarkan prakarsa 
masyarakat, hak asal usul dan hak tradisional yang diakui dan dihormati dalam sistem Pemerintahan Negara Kesatuan Republik Indonesia. Sumber pendapatan dana desa yaitu pendapatan asli desa, dana desa yang bersumber dari Anggaran Pendapatan Dan Belanja Negara (APBN), bagian dari hasil Pajak Daerah Dan Retribusi Daerah (PDRD) Kab/Kota, Alokasi dana desa yang berasal dari Kabupaten, bantuan keuangan dari APBD provinsi dan APBD Kabupaten, Hibah dan sumbangan pihak ke-3 serta lain-lain pendapatan desa yang sah. Dana desa (DD) merupakan dana yang bersumber dari anggaran pendapatan dan belanja negara (APBN) bagi desa, yang ditransfer melalui anggaran belanja daerah kabupaten/kota, untuk membiayai penyelenggaraan pemerintah, pelaksanaan pembangunan, pembinaan kemasyarakatan dan pemberdayaan masyarakat desa.

Pengelolaan keuangan desa yang baik adalah pengelolaan yang sesuai dengan pedoman yang telah diatur oleh pemerintah yaitu Permendagri Nomor 20 Tahun 2018 tentang Pengelolaan Keuangan Desa. Tahapan pengelolaan keuangan desa dimulai dari perencanaan, pelaksanaan, penatausahaan, pelaporan, dan pertanggungjawaban. Anggaran pendapatan dan belanja desa (APBDes) merupakan rencana keuangan tahunan pemerintah desa, APBDes terdiri dari pendapatan desa, belanja desa, dan pembiayaan desa.

Desa Ulak Paceh merupakan salah satu desa yang terletak di Kecamatan Lawang Wetan Kabupaten Musi Banyuasin Sumatera Selatan. Desa ini memiliki luas 3.351 hektar yang terdiri dari pertanian, perkebunan, peternakan, perikanan dan permukiman. Jumlah penduduk desa ulak paceh sebanyak 3.460 jiwa yang terdiri dari 1.266 Kepala Keluarga (KK). Potensi keunggulan yang ada di Desa Ulak Paceh untuk meningkatkan pendapatan penduduk perkapita pada dasarnya adalah petani, dikarenakan lahan yang masih sangat luas dan subur. Secara administrasif Desa Ulak Paceh dibagi menjadi 6 dusun yang terdiri dari 12 RT.

Penanatausahaan akuntansi desa harus tranparan, akuntabel, dapat dipertanggungjawabkan, dan sesuai dengan Undang-Undang yang berlaku, diperlukan suatu model sistem dan prosedur penatausahaan akuntansi dana desa. Sumber Daya Manusia (SDM) pegawai penatausahaan desa kebanyakan kurang mumpuni dalam hal penatausahaan akuntansi desa sehingga diperlukan dokumentasi sistem dan prosedur akuntansi desa yang detail untuk digunakan di desa-desa di Indonesia sebagai pedoman penatausahaan akuntansi dana desa. Saat ini, sistem penatausahaan yang ada hanya berpedoman pada Undang-Undang dan belum ada pedoman sistem lengkap yang terdokumentasi.

Berdasarkan hasil observasi awal yang peneliti temukan bahwa pegawai penatausahaan akuntansi desa Ulak Paceh perlu mempelajari Undang-Undang Dan Peraturan Pemerintah ketika melakukan penatausahaan akuntansi desa. Dengan keterbatasan kompetensi mereka di bidang akuntansi dan administrasi kegiatan penatausahaan ini sangat menyulitkan mereka dikarenakan sistem akuntansi. Prosedur akuntansi sangatlah penting dalam menunjang pemerintah kota/kabupaten khususnya di dalam pemerintahan desa Ulak Paceh dalam menjalankan pengelolaan Dana desa yang baik dan sesuai dengan prosedur yang semestinya agar nanti dapat mempermudah dalam hal pelaporan dan pertanggungjawaban kepada pemerintah kabupaten dalam hal ini yang berkaitan dengan dana desa. Tujuan dari penelitian ini adalah untuk menganalisis sistem akuntansi penatausahaan APBDes pada desa Ulak Paceh Sudah Baik atau Belum.

\section{LANDASAN TEORI}

\section{Sistem Akuntansi}

Menurut Mulyadi (2016: 3) pengertian sistem akuntansi adalah organisasi formulir, catatan dan laporan yang dikoordinasi sedemikian rupa utntuk menyediakan informasi keuangan yang dibutuhkan oleh manajemen guna memudahkan pengelolaan perusahaan. 


\section{Pengertian Desa}

Menurut permendagri nomor 20 tahun 2018 tentang pengelolaan keuangan desa mengatakan: Desa adalah kesatuan masyarakat hukum yang memiliki batas wilayah yang berwenang untuk mengatur dan mengurus urusan pemerintahan, kepentingan masyarakat setempat berdasarkan prakarsa masyarakat, hak asal usul, dan/atau hak tradisional yang diakui dan dihormati dalam sistem pemerintahan Negara Kesatuan Republik Indonesia.

\section{Dana Desa}

Menurut Permendagri nomor 20 tahun 2018 tentang pengelolaan keuangan desa mengatakan bahwa "dana desa adalah dana yang bersumber dari APBN yang diperuntukkan bagi desa yang ditransfer melalui APBD kabupaten/kota dan digunakan untuk membiayai penyelenggaraan pemerintah, pelaksanaan pembangunan, pembinaan kemasyarakatan dan pemberdayaan masyarakat desa."

\section{Pengelolaan Keuangan Desa}

Pengertian Keuangan Desa menurut UU Desa adalah semua hak dan kewajiban desa yang dapat dinilai dengan uang serta segala sesuatu berupa uang dan barang yang berhubungan dengan pelaksanaan hak dan kewajiban Desa. Hak dan kewajiban tersebut menimbulkan pendapatan, belanja, pembiayaan yang perlu diatur dalam pengelolaan keuangan desa yang baik.

\section{Siklus Pengelolaan Keuangan Desa}

Menurut Permendagri No. 20 tahun 2018 mengatakan bahwa "siklus pengelolaan keuangan desa yaitu dimulai dari perencanaan, pelaksanaan, penatausahaan, pelaporan, dan pertanggungjawaban, dengan periodisasi 1 (satu) tahun anggaran, terhitung mulai tanggal 1 Januari sampai dengan 31 Desember." Gambaran rincian proses Siklus Pengelolaan Keuangan Desa adalah sebagai berikut:

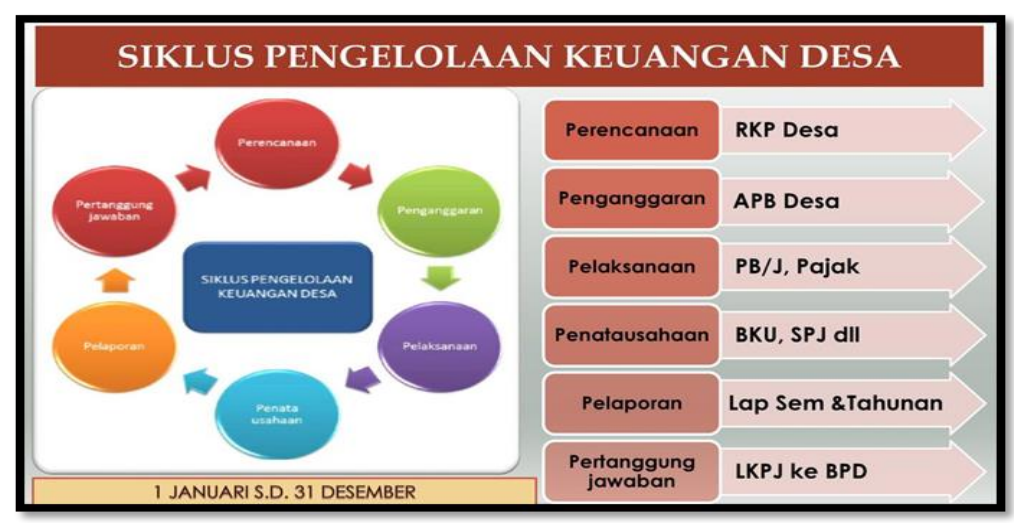

Sumber: Akuntansi Desa tahun 2016

Gambar 1. Siklus Pengelolaan Keuangan Desa

\section{Anggaran Pendapatan Dan Belanja Desa (APBDes)}

Menurut Yuliansyah \& Rusmianto (2015 : 27) "Pengertian Anggaran Pendapatan dan Belanja Desa (APBDesa) adalah rencana keuangan tahunan pemerintah desa." APBDesa merupakan dokumen formal hasil kesepakatan antara pemerintah desa dan badan permusyawaratan desa yang berisi tentang belanja yang ditetapkan untuk melaksanakan kegiatan pemerintah desa selama satu tahun dan sumber pendapatan yang diharapkan untuk menutup keperluan belanja tersebut atau pembiayaan yang diperlukan bila diperkirakan akan terjadi defisit atau surplus.

\section{Sistem Akuntansi Desa}

Sujarweni (2015: 17) Sistem akuntansi desa adalah pencatatan dari proses transaksi yang terjadi di desa, dibuktikan dengan nota nota kemudian dilakukan pencatatan dan pelaporan 
keuangan sehingga akan dihasilkan informasi dalam bentuk laporan keuangan yang digunakan pihak-pihak yang berhubungan dengan desa yaitu masyarakat desa, perangkat desa, pemeritah daerah, dan pemerintah pusat.

\section{Penatausahaan Keuangan Desa}

Menurut Permendagri No. 20 tahun 2018 mengatakan bahwa "Penatausahaan keuangan desa adalah kegiatan pencatatan yang khususnya dilakukan oleh bendahara desa, bendahara desa wajib melakukan pencatatan terhadap seluruh transaksi yang ada berupa penerimaan dan pengeluaran. Bendahara desa melakukan pencatatan secara sistematis dan kronologis atas transaksi-transaksi keuangan yang terjadi. Penatausahaan keuangan desa yang dilakukan oleh bendahara desa dilakukan dengan cara sederhana, yaitu berupa pembukuan belum menggunakan jurnal akuntansi".

Bendahara Desa menggunakan Buku Kas Umum, Buku Kas Pembantu Pajak dan Buku Bank dalam melakukan pencatatan. Bendahara desa melakukan pencatatan atas seluruh penerimaan dan pengeluaran dalam Buku kas umum untuk yang bersifat tunai. Sedangkan transaksi penerimaan dan pengeluaran yang melalui bank/transfer dicatat dalam buku bank. Buku kas pembantu pajak digunakan oleh bendahara desa untuk mencatat penerimaan uang yang berasal dari pungutan pajak dan mencatat pengeluaran berupa penyetoran pajak ke kas negara. Khusus untuk pendapatan dan pembiayaan, terdapat buku pembantu berupa buku rincian pendapatan dan buku rincian pembiayaan.

\section{Siklus penatausahaan keuangan desa}

Jenis transaksi yang terjadi dalam keuangan desa adalah transaksi penerimaan dan pengeluaran kas. Penerimaan kas oleh pemerintah desa berdasarkan permendagri No. 20 tahun 2018 terdiri dari pendapatan desa yang bersumber dari pendapatan asli desa, pendapatan transfer, pendapatan lain-lain, ataupun yang bersumber dari penerimaan pembiayaan. Sedangkan pengeluaran kas oleh pemerintah desa dapat berupa belanja pada berbagi bidang misalnya bidang penyekenggara pemerintah desa, bidang peleksanaan pembangunan desa, bidang pembinaan masyarakat. Berikut siklus penatausahaan keuangan menurutPermendagri Nomor 20 tahun 2018 yang dapat dilaksanakan oleh bendahara desa:

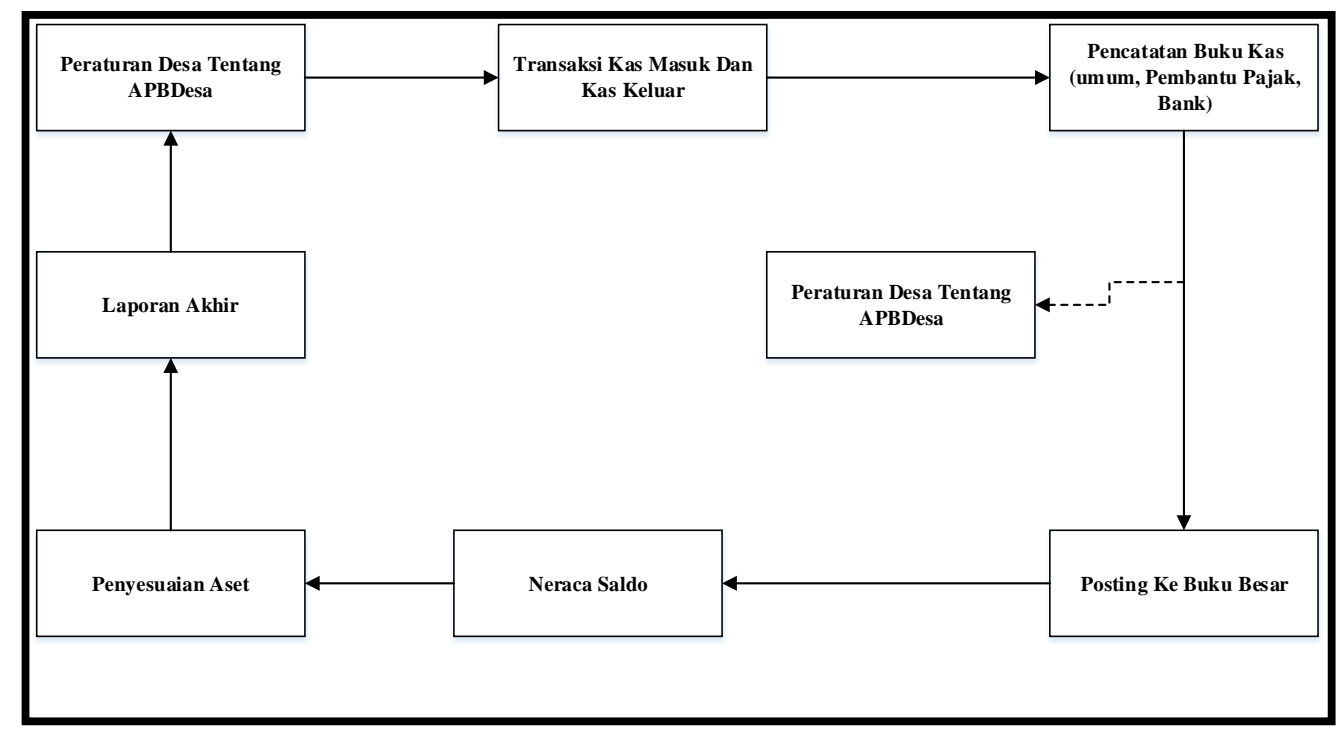

Sumber: Permendagri No. 20 Tahun 2018

Gambar 2. Siklus Penatausahaan Keuangan

148 | Eka Sevtia Mesta, Ryan Al Rachmat; Analysis of the Village Revenue and... 
Keterangan:

1. Siklus penatausahaan keuangan desa dimulai dengan ditetapkannya peraturan desa tentang Anggaran Pendapatan dan Belanja Desa (APBDesa).

2. Berdasarkan APBDesa maka pemerintahan desa melakukan transaksi keuangan berupa penerimaan kas sebagai sumber pendapatan desa dan melakukan pengeluaran kas berupa belanja untuk menjalankan operasional dan program- program desa.

3. Berdasarkan bukti-bukti transaksi keuangan (kas masuk maupun kas keluar) yang sah terutama Surat Permintaan Pembayaran dan Bukti Penerimaan Kas, bendahara desa mencatatnya dalam buku-buku kas (buku kas umum, buku pembantu pajak, dan buku bank).

4. Bendahara desa melakukan penutupan pada setiap bulannya terhadap masing-masing buku kas tersebut dan menjadikannya sebagai laporan ke kepala desa.

5. Bendahara desa memposting setiap transaksi yang dicatat di buku kas ke masing- masing akun/rekening yang ada di buku besar.

6. Pada saat akan menyusun laporan keuangan, baik semesteran maupun tahunan, bendahara desa harus menyusun neraca saldo yang merupakan ringkasan saldo dari setiap akun/rekening yang ada di buku besar.

7. Selanjutnya bendahara desa menghitung dan melakukan penyesuaian terhadap akunakun/rekening-rekening yang terkait dengan aset lancar sebagai tahap penyusunan laporan kekayaan milik desa.

8. Bendahara desa menyusun laporan keuangan.

\section{Laporan Keuangan Desa}

Menurut permendagri nomor 20 tahun 2018 mengatakan “Laporan keuangan desa yang wajib dilaporkan oleh pemerintah desa berupa anggaran, buku kas, buku pajak, buku bank, dan laporan realisasi anggaran."

Dalam bukunya Sujarweni (2015: 23)

Tahapan pembuatan laporan keuangan desa adalah sebagai berikut:

1. Membuat rencana berdasarkan visi misi yang dituangkan dalam penyusunan anggaran.

2. Anggaran yang dibuat terdiri atas akun pendapatan, belanja, dan pembiayaan. Setelah disahkan, anggaran perlu dilaksanakan.

3. Dalam pelaksanaan anggaran, timbul transaksi yang harus dicatat secara lengkap berupa pembuatan buku kas umum, buku kas pembantu, buku bank, buku pajak, buku inventaris dengan disertai pengumpulan bukti bukti transaksi.

\section{Pertanggungjawaban Keuangan Desa}

Menurut permendagri nomor 113 tahun 2014 pertanggungjawaban keuangan desa terdiri atas hal berikut.

1. Kepala desa menyampaikan laporan pertanggungjawaban realisasi pelaksanaan APBDes kepada bupati/walikota melalui camat setiap akhir tahun anggaran. Laporan pertanggungjawaban realisasi pelaksanaan APBDes terdiri atas pendapatan, belanja, dan pembiayaan. Laporan ini ditetapkan peraturan desa dengan melampirkan format:

a Laporan pertanggungjawaban realisasi pelaksanaan APBDesa tahun anggaran berkenaan;

b Laporan kekayaan milik desa per 31 desember tahun anggaran berkenaan; dan

2. Laporan pertanggungjawaban realisasi pelaksanaan APBDes disampaikan paling lambat satu bulan setelah akhir tahun anggaran berkenaan.

\section{METODE PENELITIAN}

Data yang digunakan penulis dalam penelitian ini data primer yaitu data yang didapat dari wawancara langsung dengan sekretaris desa ulak paceh untuk data sekunder yaitu sistem 
penerimaan Anggaran Pendapatan Dan Belanja Desa (APBDes) melalui bendahara desa dan sistem penerimaan Anggaran Pendapatan Dan Belanja Desa (APBDes) melalui transfer. Sejarah singkat, struktur organisasi, tugas dan fungsi, dan data lainnya yang diperlukan serta buku-buku, undangundang dan peraturan pemeritah yang digunakan oleh penulis dalam menunjang

Teknik analisis penelitian ini adalah penelitian Kualitatif, yaitu mengumpulkan data dalam bentuk wawancara, observasi, dan dokumentasi yang berkaitan dengan prosedur penatausahaan akuntansi desa kemudian data tersebut dijadikan acuan dalam Analisis sistem serta dokumen transaksi dalam bentuk narasi dan flowchart beserta rancangan dokumen transaksinya

\section{HASIL DAN PEMBAHASAN}

\section{Analisis Sistem Akuntansi Penatausahaan Anggaran Pendapatan Dan Belanja Desa (APBDes) Pada Desa Ulak Paceh}

Penerimaan desa adalah uang yang berasal dari semua pendapatan desa yang masuk ke APBDes melalui Rekening Kas Desa atau yang diterima oleh Bendahara Desa. Bendahara desa wajib melakukan pencatatan setiap ada penerimaan di kas desa. Penerimaan pendapatan desa bisa berasal dari Pendapatan asli daerah, Alokasi Anggaran Pendapatan dan Belanja Negara (Dana Desa), bagian hasil pajak Daerah dan Retribusi Daerah Kabupaten/Kota, Alokasi Dana Desa, Bantuan keuangan dari APBD Provinsi dan APBD Kabupaten/Kota, Hibah dan Sumbangan yang tidak mengikat dari Pihak Ketiga, dan Lain-lain Pendapatan yang Sah. Pencairan dana dalam rekening desa ditandatangani oleh Kepala Desa dan Bendahara Desa. Metode pencatatan penatausahaan penerimaan desa terdiri dari buku kas umum, buku pembantu pajak, dan buku kas bank. Kegiatan penatausahaan Anggaran Pendapatan dan Belanja Desa (APBDes) pada desa Ulak Paceh sudah sesuai dengan Permendagri No. 20 tahun 2018 tentang pengolaan keuangan desa.

\section{Pengendalian Intern pada Analisis Sistem Akuntansi Penatausahaan Anggaran Pendapatan Dan} Belanja Desa (APBDes) Pada Desa Ulak Paceh

Komponen yang ada pada sistem pengendalian intern Sistem Akuntansi penatausahaan Anggaran pendapatan dan belanja desa (APBDes) Pada Desa Ulak Paceh:

1. Struktur organisasi pada desa Ulak Paceh telah memenuhi pengendalian internal yang baik dan berjalan efektif dimana desa Ulak Paceh memiliki struktur organisasi yang jelas dan tidak sering berubah yang dapat menggambarkan garis wewenang serta tanggung jawab karyawannya. Pemisahan fungsi dalam struktur organisasinya pun tidak menyebabkan adanya bagian yang merangkap tugas dan jabatan pada bagian lain serta penetapan sanksi kepada pengelola yang melanggar aturan yang ditetapkan.

2. Sistem otorisasi dan prosedur pencatatan pada desa Ulak Paceh telah berjalan efektif dimana dalam pemberian kredit dan pemberian otorisasi serta dokumen yang digunakan jelas dan tepat. Pengelola menjalankan tanggung jawabnya sesuai wewenang yang diberikan, transaksi yang diproses adalah transaksi yang telah terotorisasi, pemberian otorisasi kredit didelegasikan pada bagian kredit untuk mengontrol prosedur dalam tiap transaksinya, penginputan data dilakukan secara akurat dan tepat.

3. Praktik yang sehat pada desa Ulak Paceh telah berjalan efektif dimana penggunaan formulir juga lengkap dengan faktur pemberian kredit bernomor urut, pemakaian faktur pemberian kredit dapat dipertanggung jawabkan oleh fungsi kredit. Dimana terdapatnya pemeriksaan atas keabsahan blangko dan juga melakukan penilaian atau evaluasi kredit oleh tim verifikasi serta melakukan kunjungan lapangan oleh tim verifikasi dan juga memberikan umpan balik oleh tim verifikasi. Catatan arsip desa Ulak Paceh juga disimpan dan di arsip dengan baik. Desa Ulak Paceh juga melakukan evaluasi atas kebijakan yang ada didalam desa Ulak Paceh serta memberikan sanksi untuk setiap pelanggaran yang dilakukan dengan sengaja.

4. Pengelola yang bermutu pada desa Ulak Paceh berjalan dengan efektif dimana penerimaan pengelola baru sering dilakukan pada desa Ulak Paceh.

150 | Eka Sevtia Mesta, Ryan Al Rachmat; Analysis of the Village Revenue and... 
Analisis sistem akuntansi ini sebagai dasar penulis mengetahui bagaimana sistem akuntansi penatausahaan APBDes pada desa Ulak Paceh. Dalam pencatatanya masih manual belum ada sistem tersendiri untuk pencatatnya atau masih dibantu dengan Microsoft Excel yang berupa Buku Kas Umum, Buku Kas Pembantu pajak, dan Buku Buku Bank serta Laporan Realisasi Anggaran tahap pertama dan tahap kedua, Semua Penerimaan kas juga sudah didukung oleh bukti yang lengkap dan sah. Prosedur pentausahaan penerimaan yang digunakan dalam Analisis sistem akuntansi penatausahaan APBDes pada desa ulak paceh yaitu:

a. Prosedur penerimaan melalui bendahara desa

Penyetoran langsung melalui bendahara desa oleh pihak ketiga dilakukan sesuai prosedur dan tatacara sebagai berikut:

1. Pihak ketiga/penyetor mengisi Surat Tanda Setoran (STS)/tanda bukti lain.

2. Bendahara desa menerima uang dan mencocokan dengan STS dan tanda bukti lainya.

3. Bendahara desa mencatat semua penerimaan

4. Bendahara desa menyetor penerimaan ke rekening kas desa

5. Bendahara desa dilarang membuka rekening atas nama pribadi di bank dengan tujuan pelaksanaan APBDes.

6. Bukti setoran dan bukti penerimaan lainnya harus dipertanggungjawabkan kepada Kepala Desa.

7. Bendahara desa dilarang menyimpan uang, cek atau surat berharga, kecuali telah diatur melalui peraturan perundang-undangan.

b. Prosedur penerimaan setoran melalui bank adalah :

1. Bank yg ditunjuk oleh Pemerintah Desa dlm rangka menyimpan uang dan surat berharga lainnya yang ditetapkan sebagai rekening kas desa.

2. Pihak ketiga/penyetor mengisi STS/tanda bukti lain sesuai ketentuan yg berlaku. Dokumen yg digunakan oleh bank meliputi :

a.STS/Slip setoran

b.Bukti penerimaan lain yg sah

3. Pihak ketiga/penyetor menyampaikan pemberitahuan penyetoran yg dilakukan melalui bank kepada bendahara desa dengan dilampiri bukti penyetoran/slip setoran bank yg sah.

4. Bendahara desa mencatat semua penerimaan yg disetor melalui bank di Buku Kas Umum dan Buku Pembantu bank berdasarkan bukti penyetoran/slip setoran bank.

Perbandingan Penatausahaan (Teori Permendagri Nomor 20 Tahun 2018) Anggaran Pendapatan Dan Belanja Desa (APBDes) Pada Desa Ulak Paceh

Tabel 1. Perbandingan Penatausahaan Anggaran Pendapatan Dan Belanja Desa (APBDes) pada desa Ulak Paceh

\begin{tabular}{|c|c|c|c|c|}
\hline No. & Data & Menurut teori & Desa ulak paceh & Keterangan \\
\hline 1 & $\begin{array}{l}\text { Metode } \\
\text { pencatatan }\end{array}$ & $\begin{array}{l}\text { 1. Buku kas umum digunakan } \\
\text { untuk mencatat semua } \\
\text { transaksi, baik pengeluaran } \\
\text { maupun penerimaan yang } \\
\text { berkaitan dengan kas (uang } \\
\text { tunai). } \\
\text { 2. Buku pembantu pajak yang } \\
\text { digunakan untuk mencatat } \\
\text { semua transaksi penerimaan } \\
\text { maupun penngeluaran pajak } \\
\text { (khususnya PPh pasal } 21 \text { dan } \\
\text { PPn), dalam kaitannya } \\
\text { bendahara desa sebagai } \\
\text { wajib pungut (wapu). }\end{array}$ & $\begin{array}{l}\text { 1. buku kas umum digunakan } \\
\text { untuk penerimaan yang bersifat } \\
\text { tunai yang diterima oleh } \\
\text { bendahara desa dibuatkan bukti } \\
\text { kuitansi tanda terima dan } \\
\text { dicatat oleh bendahara desa } \\
\text { pada buku kas umum. } \\
\text { 2. Buku pembantu pajak } \\
\text { digunakan untuk mencatat } \\
\text { pungutan/potongan yang } \\
\text { dilakukan oleh bendahara desa } \\
\text { serta pencatatan penyetoran ke } \\
\text { kas negara sesuai dnegan } \\
\text { ketentuan perundangan, atas }\end{array}$ & Sudah Sesuai \\
\hline
\end{tabular}




\begin{tabular}{|c|c|c|c|c|c|c|}
\hline & & & $\begin{array}{l}\text { Buku bank digunakan untuk } \\
\text { mencatat semua transaksi, } \\
\text { baik penerimaan maupun } \\
\text { pengeluaran yang terkait } \\
\text { dengan bank (penarikan, } \\
\text { penyetoran, dll). }\end{array}$ & & $\begin{array}{l}\text { pungutan/potongan } \\
\text { penyetoran pajak ini tidak } \\
\text { dilakukan pada buku kas umum } \\
\text { hanya pada buku pembantu } \\
\text { pajak. } \\
\text { Buku bank digunakan untuk } \\
\text { penerimaan yang bersifat } \\
\text { transfer, bendahara desa akan } \\
\text { mendapatkan informasi dari } \\
\text { bank berupa nota kredit atas } \\
\text { dana-dana yang masuk ke } \\
\text { rekening kas desa, berdasarkan } \\
\text { nota kredit ini seanjutnya } \\
\text { bendahara desa melakukan } \\
\text { pencatatan ke dalam buku } \\
\text { bank. }\end{array}$ & \\
\hline 2 & $\begin{array}{l}\text { Fungsi } \\
\text { penerimaan }\end{array}$ & & $\begin{array}{l}\text { Penatausahaan keuangan } \\
\text { dilakukan oleh kaur } \\
\text { keuangan sebagai fungsi } \\
\text { bendahara. } \\
\text { Sekretaris desa melakukan } \\
\text { verifikasi, evaluasi dan } \\
\text { analisis atas laporan. } \\
\text { Rekening kas desa } \\
\text { digunakan untuk } \\
\text { penerimaan dana yang } \\
\text { ditranfer oleh pemerintah } \\
\text { ataupun pihak ketiga. }\end{array}$ & 2. & $\begin{array}{l}\text { Pemberi dana berfungsi } \\
\text { menyalurkan dana desa atau } \\
\text { bantuan keuangan pada desa } \\
\text { berdasarkan ketentuan yang } \\
\text { berlaku. } \\
\text { Penerima dana bertugas } \\
\text { menerima dana yang masuk } \\
\text { untuk desa. } \\
\text { Bank berfungsi mengeluarkan } \\
\text { nota kredit atas dana-dana yang } \\
\text { masuk ke rekening kas desa. }\end{array}$ & Sudah selesai \\
\hline 3 & $\begin{array}{l}\text { Dokumen } \\
\text { penatausahaa } \\
\text { n penerimaan }\end{array}$ & & $\begin{array}{l}\text { Bukti kuitansi penerimaan } \\
\text { Pada desa ulak paceh } \\
\text { penerimaan secara tunai } \\
\text { yang diterima oleh } \\
\text { bendahara desa dibuatkan } \\
\text { bukti kuitansi tanda terima } \\
\text { dan dicatat oleh bendahara } \\
\text { pada buku kas umum. } \\
\text { Nota kredit Pada desa ulak } \\
\text { paceh nota kredit digunakan } \\
\text { sebagai dokumen yang } \\
\text { membuktikan terjadinya } \\
\text { pengurangan piutang. } \\
\text { Bukti setor pajak Pada desa } \\
\text { ulak paceh bukti setor pajak } \\
\text { merupaka bukti pembayaran } \\
\text { atau penyetoran pajak yang } \\
\text { telah dilakukan oleh wajib } \\
\text { pajak dengan menggunakan } \\
\text { formulir atau dengan cara } \\
\text { lain ke kas negara, wajib } \\
\text { pajak diharuskan terlebih } \\
\text { dahulu untuk membuat } \\
\text { Surat Setoran Pajak (SPP) } \\
\text { dan membawa SPP tersebut } \\
\text { ke tempat membayar pajak. } \\
\text { desa ulak paceh bukti }\end{array}$ & 1. & $\begin{array}{l}\text { Nota kredit Pada desa Ulak } \\
\text { Paceh nota kredit digunakan } \\
\text { sebagai dokumen yang } \\
\text { membuktikan terjadinya } \\
\text { pengurangan piutang. } \\
\text { Bukti setor pajak Pada desa } \\
\text { ulak paceh bukti setor pajak } \\
\text { merupaka bukti pembayaran } \\
\text { atau penyetoran pajak yang } \\
\text { telah dilakukan oleh wajib } \\
\text { pajak dengan menggunakan } \\
\text { formulir atau dengan cara lain } \\
\text { ke kas negara, wajib pajak } \\
\text { diharuskan terlebih dahulu } \\
\text { untuk membuat Surat Setoran } \\
\text { Pajak (SPP) dan membawa SPP } \\
\text { tersebut ke tempat membayar } \\
\text { pajak. } \\
\text { Bukti transfer bank Pada } \\
\text { desa ulak paceh bukti transfer } \\
\text { bank didapat setelah } \\
\text { melakukan transaksi pada } \\
\text { bank, bukti transaksi menjadi } \\
\text { alat untuk merekam seluruh } \\
\text { transaksi yang terjadi. } \\
\text { Bukti kuitansi penerimaan } \\
\text { Pada desa ulak paceh } \\
\text { penerimaan secara tunai yang }\end{array}$ & Sesuai selesai \\
\hline
\end{tabular}




\begin{tabular}{|l|l|l|l|l|}
\hline & $\begin{array}{l}\text { transfer bank didapat } \\
\text { setelah melakukan transaksi } \\
\text { pada bank, bukti transaksi } \\
\text { menjadi alat untuk merekam } \\
\text { seluruh transaksi yang } \\
\text { terjadi. }\end{array}$ & $\begin{array}{l}\text { dibuatkan bukti kuitansi tanda } \\
\text { terima dan dicatat oleh } \\
\text { bendahara pada buku kas } \\
\text { umum. }\end{array}$ & \\
\hline
\end{tabular}

\section{Dokumen Yang Digunakan dalam Analisis Sistem Akuntansi Penatausahaan Anggaran Pendapatan} Dan Belanja Desa (APBDes) Pada Desa Ulak Paceh

1. Bukti kuitansi penerimaan

Pada desa Ulak Paceh penerimaan secara tunai yang diterima oleh bendahara desa dibuatkan bukti kuitansi tanda terima dan dicatat oleh bendahara pada buku kas umum.

2. Nota kredit

Pada desa ulak paceh nota kredit digunakan sebagai dokumen yang membuktikan terjadinya pengurangan piutang.

3. Bukti setor pajak

Pada desa ulak paceh bukti setor pajak merupaka bukti pembayaran atau penyetoran pajak yang telah dilakukan oleh wajib pajak dengan menggunakan formulir atau dengan cara lain ke kas negara, wajib pajak diharuskan terlebih dahulu untuk membuat Surat Setoran Pajak (SPP) dan membawa SPP tersebut ke tempat membayar pajak.

4. Bukti transfer bank

Pada desa ulak paceh bukti transfer bank didapat setelah melakukan transaksi pada bank, bukti transaksi menjadi alat untuk merekam seluruh transaksi yang terjadi.

Fungsi-Fungsi Yang Terlibat Analisis Sistem Akuntansi Penatausahaan Anggaran Pendapatan Dan Belanja Desa (APBDes) Pada Desa Ulak Paceh

Ada beberapa fungsi yang digunakan desa ulak paceh dalam Analisis Sistem Akuntansi Penatausahaan Anggaran Pendapatan Dan Belanja Desa (APBDes) yaitu:

1. Pemberi dana terdiri dari pemerintah pusat/provinsi/kabupaten/kota, pihak ketiga, masyarakat. Desa menerima pendapatan transfer desa yang berasal dari pemerintah supra desa yang menyalurkan dana atau bantuan keuangan pada desa berdasarkan ketentuan yang berlaku.

2. Penerima dana desa terdiri dari bendahara desa, pelaksana kegiatan dan kepala desa.

3. Bank berfungsi sebagai penyedia fasilitas penyimpanan dana masyarakat dalam bentuk giro, tabungan maupun deposito dan dapat dimaanfaatkan oleh masyarakat untuk memenuhi berbagai kebutuhan.

\section{Prosedur (flowchart) Analisis Sistem Akuntansi Penatausahaan Anggaran Pendapatan Dan Belanja Desa (APBDes) Pada Desa Ulak Paceh}

Berikut ini usulan prosedur (flowchart) yang penulis rancang untuk menggambarkan alur kegiatan penatausahaan anggaran pendapatan dan belanja desa (APBDes) Pada Desa Ulak Paceh

a. Prosedur penerimaan melalui bendahara desa

Penyetoran langsung melalui bendahara desa oleh pihak ketiga dilakukan sesuai prosedur dan tatacara sebagai berikut:

1. Pihak ketiga/penyetor mengisi Surat Tanda Setoran (STS)/tanda bukti lain.

2. Pihak ketiga/penyetor memberikan uang kepada bendahara desa.

3. Bendahara desa menerima uang dan mencocokan dengan STS dan tanda bukti lainya.

4. Bendahara desa mencatat semua penerimaan.

5. Bendahara desa menyetor penerimaan ke rekening kas desa 
6. Bendahara desa dilarang membuka rekening atas nama pribadi di bank dengan tujuan pelaksanaan APBDes.

7. Bukti setoran dan bukti penerimaan lainnya harus dipertanggungjawabkan kepada Kepala Desa.

8. Bendahara desa dilarang menyimpan uang, cek atau surat berharga, kecuali telah diatur melalui peraturan perundang-undangan.

b. Prosedur penerimaan setoran melalui bank adalah :

1. Bank yg ditunjuk oleh Pemerintah Desa dlm rangka menyimpan uang dan surat berharga lainnya yang ditetapkan sebagai rekening kas desa.

2. Pihak ketiga/penyetor mengisi STS/tanda bukti lain sesuai ketentuan yg berlaku. Dokumen yg digunakan oleh bank meliputi :

a. STS/Slip setoran

b. Bukti penerimaan lain yg sah

3. Pihak ketiga/penyetor menyampaikan pemberitahuan penyetoran yg dilakukan melalui bank kepada bendahara desa dengan dilampiri bukti penyetoran/slip setoran bank yg sah.

4. Bendahara desa mencatat semua penerimaan yg disetor melalui bank di Buku Kas Umum dan Buku Pembantu bank berdasarkan bukti penyetoran/slip setoran bank.

\section{Kesimpulan}

\section{KESIMPULAN DAN SARAN}

1. Analisis sistem akuntansi penatausahaan penatausahaan Anggaran Pendapatan Dan Belanja Desa pada (APBDes) desa Ulak Paceh ada 3 (tiga) yaitu:

a) Metode pencatatan menurut teori ada 3 (tiga) yaitu buku kas umum, buku kas pembantu pajak dan buku bank. Sedangkan pada desa ulak paceh ada 3 buku kas umum, buku kas pembantu pajak dan buku bank. Hal ini bearti metode pencatatan pada desa Ulak Paceh sudah sesuai dengan teori.

b) Fungsi penerimaan kas menurut teori ada 3 (tiga) pemberi dana, penerima dana dan bank. Sedangkan pada desa ulak paceh ada 3 pemberi dana (pemerintah pusat/provinsi/kabupaten/kota, pihak ketiga dan masyarakat), penerima dana ( bendahara desa, pelaksana kegiatan dan kepala desa) dan Bank. Hal ini bearti fungsi penerimaan pada desa Ulak Paceh sudah sesuai dengan teori.

c) Dokumen penatausahaan penerimaan menurut teori ada 4 (empat) yaitu: kuitansi penerimaan, nota kredit, bukti setor pajak, bukti transfer bank. Sedangkan pada desa Ulak Paceh ada 4 (empat) yaitu kuitansi penerimaan, nota kredit, bukti setor pajak, bukti transfer bank. Hal ini bearti metode pencatatan pada desa Ulak Paceh sudah sesuai dengan teori.

2. Dengan adanya Analisis sistem akuntansi penatausahaan APBDes pada desa Ulak Paceh yang dibuat dapat mendukung kegiatan penatausahaan APBDes pada desa Ulak Paceh.

\section{Saran}

Sebaiknya pengawai penatausahaan pada desa Ulak Paceh perlu mempelajari undangundang dan peraturan pemerintah ketika melakukan penatausahaan akuntansi desa agar tidak menyulitkan mereka dalam melaksanakan kegiatan penatausahaan penerimaan APBDes pada desa Ulak paceh.

Perlu adanya sistem akuntansi yang lebih baik agar nantinya pelaporan Dana desa mampu dilakukan dengan cepat dan output laporan keuangan desa lebih handal 
Mulyadi. 2016. Sistem Informasi Akuntansi. Jakarta: Salemba Empat.

Peraturan Menteri Dalam Negeri No. 20 Tahun 2018 Tentang Pengelolaan Keuangan Desa.

Peraturan Menteri Dalam Negeri Nomor 113 Tahun 2014 tentang Pengelolaan Keuangan Desa.

Sujarweni V. Wiratna. 2015. Sistem Akuntansi. Yogyakarta: Pustaka Baru Press.

Yuliansyah dan Rusmianto. 2017. Akuntansi Desa. Jakarta: Salemba Empat 